\title{
Comparison of ELISA and RIA for measurement of pneumococcal antibodies before and after vaccination with 14-valent pneumococcal capsular polysaccharide vaccine
}

\author{
M KOSKELA AND MAIJA LEINONEN \\ From the Department of Medical Microbiology, University of Oulu, Oulu, Finland
}

SUMMARY Antibody responses to the 14-valent pneumococcal capsular polysaccharide vaccine in children under school age were measured by enzyme-linked immunosorbent assay (ELISA) and radioimmunoassay (RIA). Specific IgG and IgM antibodies were usually detectable by ELISA in the prevaccination sera, and one or both of them increased as a response to the vaccination. Specific IgA antibodies were detected by ELISA in a part of the post-vaccination sera only. The frequency of the IgA responses increased with the age of the children. The correlation of the ELISA results with RIA was good ( $\mathrm{r}$ from 0.652 to 0.812$)$ except for type $6 \mathrm{~A}(\mathrm{r}=0.471)$.

Antibodies against pneumococcal polysaccharides are most often measured by passive haemagglutination ${ }^{12}$ or by radioimmunoassay (RIA), based on the Farr technique. ${ }^{3}$ The indirect immunofluorescence method has been used for detecting pneumococcal antibodies of different immunoglobulin classes in either serum or different secretions. ${ }^{4-7}$ Recently also the enzyme-linked immunosorbent assay (ELISA) has been applied to measure pneumococcal antibodies in the sera of adults. ${ }^{8-11}$

The method most commonly used for measuring antibody responses to pneumococcal vaccines and for evaluating the immunogenicity of their individual polysaccharide components has been radioimmunoassay. ${ }^{12-14}$ This method in its commonly used form does not tell us which immunoglobulin classes participate in the antibody response to the vaccine. This information may, on the other hand, be especially pertinent when the vaccines are given to young children, whose responses to the polysaccharides are weaker than those of adults. ${ }^{12}$

We have therefore applied the ELISA method to measure the IgG, IgM, and IgA pneumococcal antibodies in sera of young children before and after vaccination with the currently used 14-valent pneumococcal vaccine. The results are compared with the total antibody values, measured by RIA,

Accepted for publication 4 June 1980 to polysaccharides of six pneumococcal types commonly found in infections of this age group.

\section{Material and methods}

SERUM SPECIMENS

The sera were obtained from 29 children vaccinated intramuscularly with 14-valent pneumococcal capsular polysaccharide vaccine (Lot 719-5 of Merck Sharp and Dohme Research Laboratories, West Point, $\mathrm{Pa}$ ) containing $50 \mu \mathrm{g}$ of each capsular polysaccharide of the types $1,2,3,4,6 \mathrm{~A}, 7 \mathrm{~F}, 8,9 \mathrm{~N}$, $12 \mathrm{~F}, 14,18 \mathrm{C}, 19 \mathrm{~F}, 23 \mathrm{~F}$, and $25 \mathrm{in} 0.5 \mathrm{ml}$. Seven children under 2 years of age received a primary injection of $0.25 \mathrm{ml}$ and a booster dose of $0.25 \mathrm{ml}$ two months later, whereas 22 older children (2-7 years) received a single injection of $0.5 \mathrm{ml} .{ }^{15}$ Blood samples were taken from the cubital vein before and two to three weeks after the first injection, and again two to three weeks after the booster. The sera were immediately separated and stored at $-20^{\circ} \mathrm{C}$ until used.

\section{RIA FOR PNEUMOCOCCAL ANTIBODIES}

The sera were assayed for antibodies to the polysaccharides of the six most common pneumococcal types (types 3, 6A, 14, 18C, 19F, and 23F) causing otitis media in Finnish children. ${ }^{15}$ The tests were performed by the method of Schiffman and Aus- 
trian. ${ }^{3}$ The standard sera and ${ }^{14} \mathrm{C}$-labelled pneumococcal capsular polysaccharide antigens were prepared by Dr Schiffman, Downstate Medical Center, NY 11203, and provided for us by MSDRL. The results were expressed as $\mathrm{ng}$ of antibody nitrogen per $\mathrm{ml}$ of the serum (ng Ab N/ml) calculated on the basis of the standard sera and will in this paper be called 'RIA antibody'.

\section{ELISA FOR PNEUMOCOCCAL ANTIBODIES}

The sera were assayed against the same six pneumococcal capsular polysaccharide types. The purified pneumococcal polysaccharides were prepared and provided by MSDRL. The tests were carried out in disposable polystyrene-nine-microcuvette blocks (Finnpipette-Labsystems, Helsinki, Finland). The purified polysaccharides were dissolved in phosphate buffered saline (PBS), pH 7.2, and adsorbed on to the cuvettes by incubation with $225 \mu$ l of the polysaccharide solution (at predetermined optimal concentration varying from 10 to $20 \mu \mathrm{g} / \mathrm{ml}$ ) for 6 hours at $+37^{\circ} \mathrm{C}$ and then overnight at $+4^{\circ} \mathrm{C}$. The sensitised cuvettes were washed three times for 10 minutes with $1 \mathrm{ml}$ of PBS, pH 7.2, containing $0.05 \%$ Tween 20 (PBS-Tween) before being used. The sera were diluted $1: 50,1: 100$, and $1: 200$, etc. with PBSTween. All tests were performed in triplicate; $200 \mu \mathrm{l}$ of the serum dilutions were added to the sensitised cuvettes and incubated for 6 hours at room temperature. After the cuvettes had been washed three times as before with PBS-Tween, $200 \mu 1$ of the appropriate conjugate dilution were added. Alkaline phosphate conjugated swine antihuman IgG, IgM, and IgA were from Orion Diagnostica, Helsinki, Finland. The conjugates were diluted in PBS-Tween containing $1 \%$ bovine serum albumin (Cohns fraction V, Sigma Chemicals Co, St Louis, Mo, USA). The dilutions were 1:400 for IgG, 1:200 for IgM, and 1:250 for IgA. The cuvettes were incubated overnight (16 hours) at room temperature and washed three times as before. A fresh substrate solution was prepared each day by dissolving $200 \mathrm{mg}$ of $p$-nitrophenylphosphate (Sigma 104, Sigma Chemicals Co, St Louis, Mo, USA) in $100 \mathrm{ml}$ of 1 M diethanolamine buffer containing $1 \mathrm{mmol}$ $\mathrm{MgCl}_{2}, \mathrm{pH} 9 \cdot 8 ; 200 \mu$ l of the substrate solution were added to the cuvettes and incubated for exactly 30 minutes at $+37^{\circ} \mathrm{C}$ before the enzyme reaction was stopped by the addition of $200 \mu \mathrm{l}$ of $1 \mathrm{~N} \mathrm{NaOH}$. The optical absorbance was measured in a ninechannel photometer (FP-9 Analyzer, FinnpipetteLabsystems, Helsinki, Finland) at the wavelength of $405 \mathrm{~nm}$. As a blank we used sensitised cuvettes with the conjugate, the substrate, and the $1 N$ $\mathrm{NaOH}$ solution. The ELISA titres are given as the serum dilution giving the absorbance of 0.3 units

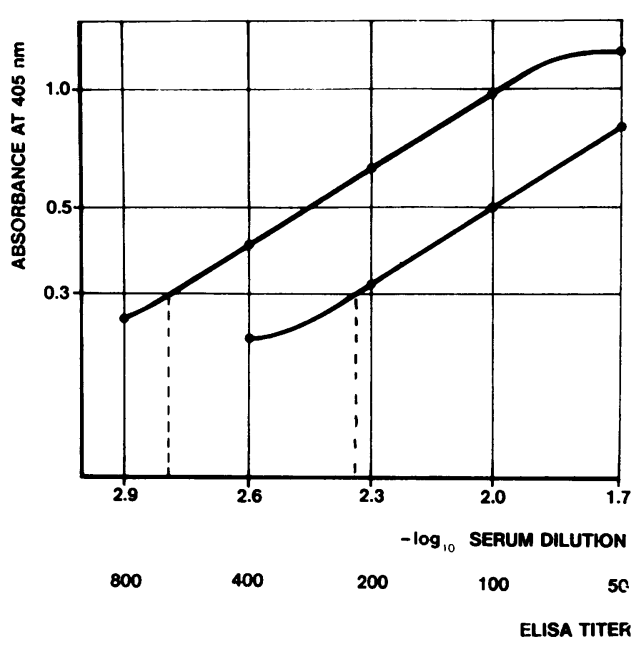

Fig. 1 The principle for the determination of ELISA titres. The ELISA titres are read from the cutting points of the linear parts of the absorbance versus serum dilution curves at 0.3 absorbance units $(405 \mathrm{~nm})$. The two curves are examples of results $(O D$ versus serum dilution) obtained with a pre-and a post-vaccination serum from one child. The dotted line shows the titre.

as shown in Fig. 1, and will in this paper be called 'ELISA antibody'.

STATISTICAL METHOD

Statistical analyses were performed by using the Pearson correlation test.

\section{Results}

Antibodies against the six pneumococcal capsular polysaccharides were detectable by RIA in all the sera studied. With the ELISA method, both IgG and IgM class antibodies were found in all the sera, whereas IgA class antibodies were detected only in part of the sera taken after the primary and booster vaccinations.

\section{REPRODUCIBILITY}

To test the reproducibility of ELISA, the same $N$ positive serum was included in each set of experi- $N$ ments performed. Its titre varied from day to day N within the limits of $\leq 0.47 \log _{10}$ units (Fig. 1). For minimising the effect of interassay variations all the sera taken from the same child were assayed in the same experiment. The ELISA titres were always $\stackrel{\circledast}{\circledast}$ corrected in relation to the reference serum. The variation of one serum tested separately in the same experiment was $\leq 0.05 \log _{10}$ units. Furthermore, the linear parts of the absorbance versus dilution curves of different kinds of sera were parallel in a single 


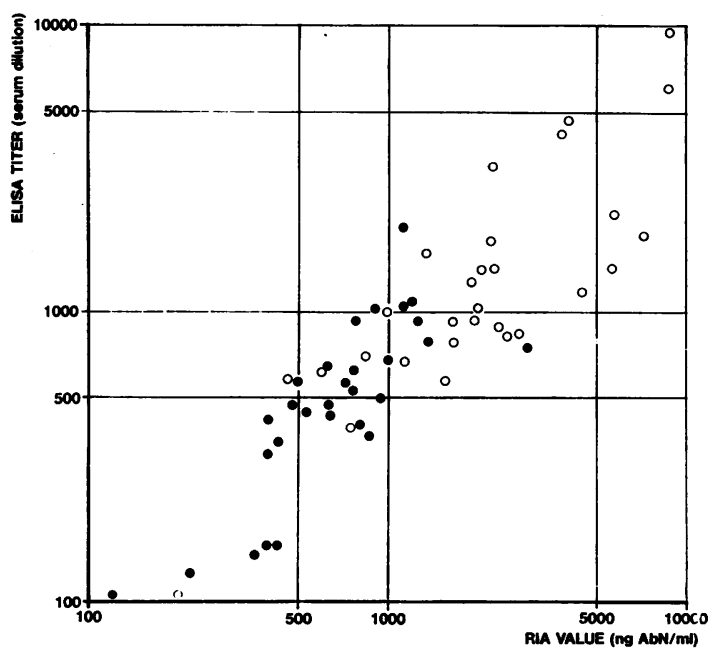

Fig. 2 Comparison of ELISA titres and RIA antibody values of anti-18C pneumococcal antibodies in sera of 29 children vaccinated with 14-valent pneumococcal capsular polysaccharide vaccine. The ELISA titres are the sum of IgG, IgM, and Ig A antibody titres registered separately: - sera taken before vaccination; $\bigcirc$ sera taken after primary vaccination.

Table 1 Correlation coefficients $(r)$ and their significance $(P)$ for the comparison of ELISA* and RIA in measuring pneumococcal antibodies $\dagger$

\begin{tabular}{lll}
\hline $\begin{array}{l}\text { Pneumococcal } \\
\text { type }\end{array}$ & $r$ & $\mathrm{P}$ \\
\hline 3 & 0.652 & $<0.001$ \\
$6 \mathrm{~A}$ & 0.471 & $<0.001$ \\
14 & 0.812 & $<0.001$ \\
$18 \mathrm{C}$ & 0.696 & $<0.001$ \\
$19 \mathrm{~F}$ & 0.681 & $<0.001$ \\
23F & 0.796 & $<0.001$ \\
\hline
\end{tabular}

*The ELISA titres are the sum of IgG, IgM, and IgA antibody titres registered separately; RIA values are $\mu \mathrm{g}$ antibody nitrogen $/ \mathrm{ml}$.

†The correlation coefficients were calculated in 58 sera of 29 children taken before and two weeks after vaccination with 14-valent pneumococcal capsular pclysaccharide vaccine.

experiment. Their slopes varied somewhat from day to day and between different conjugate types. Thus a difference of $\geq 0 \cdot 1 \log _{10}$ units corresponding to an $\geq 1.3$ fold increase or decrease in the titre was considered to be a significant difference of ELISA titres between pre, post, or booster sera

CORRELATION BETWEEN ELISA AND RIA

For evaluation of the correlation between ELISA and RIA, the sum of IgG, IgM, and IgA class ELISA antibody titre ${ }^{16}$ was compared with the total RIA antibody. The results for type $18 \mathrm{C}$ pneumococcal polysaccharide antibodies in the 29 pre- and post-vaccination sera are shown in Figure 2. The correlation coefficients (Pearson test) for the com- parison of all six polysaccharide types in 58 preor post-vaccination sera studied are shown in Table 1. For five of the types the correlation was rather strong ( $r \geq 0.65)$, whereas a weaker correlation $(r=0.471)$ was found for type 6A. The strongest correlation $(r=0.812)$ was found for type 14. The correlations were statistically significant at the level of $\mathbf{P}<\mathbf{0 . 0 0 1}$ for all six types. In general, the correlation was stronger in the post-vaccination than in the pre-vaccination sera. Furthermore, the ELISA IgG titres correlated better with the RIA values than did the ELISA IgM titres.

The geometric mean RIA and ELISA antibody values are examined in Table 2 separately for children under or over 2 years. The ELISA titres in the pre-vaccination sera of the 2-7-year-old children ranged from 400 (type 14) to 985 (type 6A) and RIA values from 225 (type 19F) to 1250 (type 23F). All antibody values were lower in the younger children (6 to 18 months). The increase of antibody level after vaccination was rather similar, independent of whether the antibodies were assayed by RIA or ELISA. The primary responses decreased in the order of type 3 (good) $>18 \mathrm{C}>19 \mathrm{~F}>23 \mathrm{~F}>14>6 \mathrm{~A}$ (poor). The antibody levels after booster vaccination were somewhat higher than the corresponding postvaccination levels in the case of types $6 \mathrm{~A}$ and 14 but were lower for all the other types, especially 3 and $23 F$.

\section{IMMUNOGLOBULIN CLASSES}

The Ig class distribution of the anti-pneumococcal antibodies is shown in Table 3. In pre-vaccination sera of the younger children (6 to 18 months old) IgM was the predominant class of anti-6A antibodies, and IgG of the anti-3, anti-18C, and anti19F antibodies. Among the generally higher prevaccination titres of the older children, a conspicuous change was the relatively larger increase of the IgM class in type 3 and especially in type $23 \mathrm{~F}$ antibodies. Usually both IgG and IgM antibodies increased after vaccination. IgG antibodies were predominant in the primary response of the younger children to types $3,14,18 \mathrm{C}$, and $19 \mathrm{~F}$, whereas among the older children IgM was the predominant class in the response to most types, and IgG only in the response to type $18 \mathrm{C}$. The decrease between the post and booster vaccination samples in total antibody levels to four of the six pneumococcal types correlated with a decrease of the IgM class.

No IgA class anti-pneumococcal antibodies were detected in the pre-vaccination sera. After primary vaccination, however, JgA antibody responses were found to each of the six pneumococcal polysaccharides, but more frequently to types $3,6 \mathrm{~A}, 18 \mathrm{C}$, and 19F (Table 4). The highest post-vaccination 
Table 2 Comparison of RIA and ELISA for measuring antibodies against six pneumococcal polysaccharides in two age groups of children vaccinated with 14-valent pneumococcal capsular polysaccharide vaccine

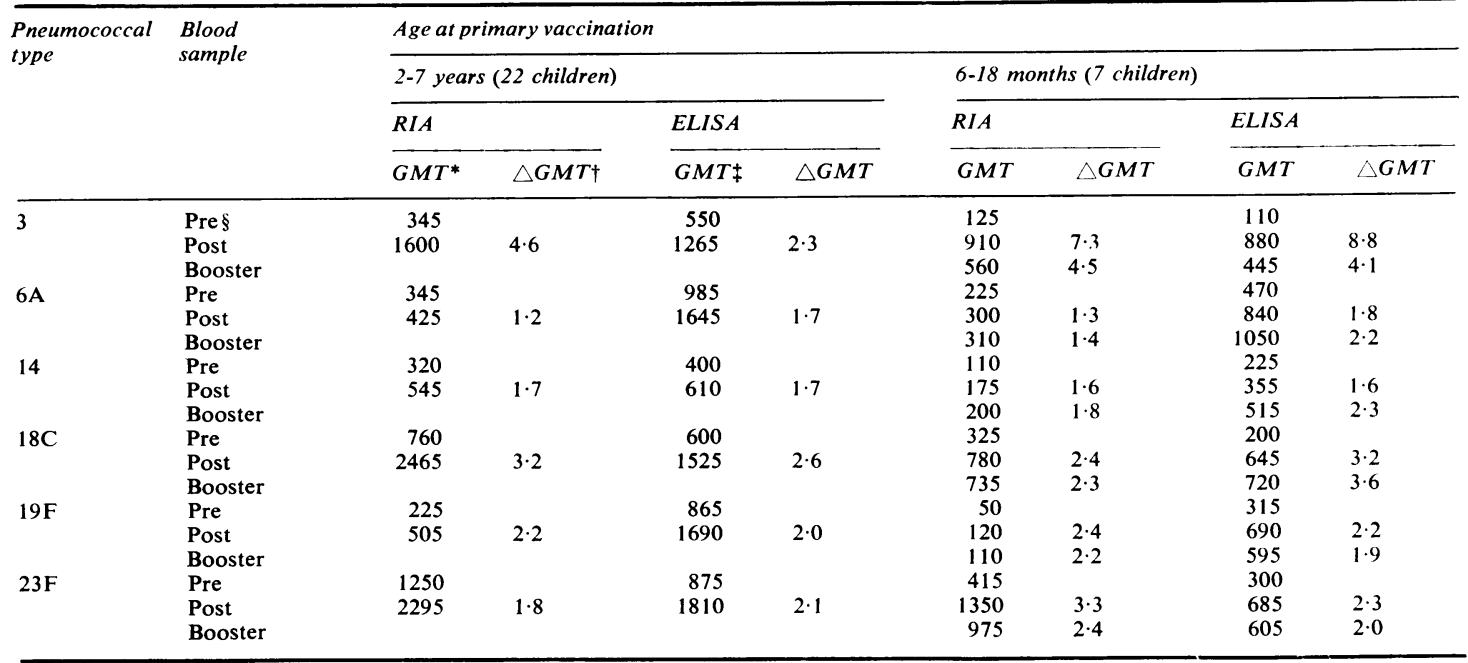

* GMT (geometric mean titre) given as ng AB N/ml.

$\dagger \triangle$ GMT: fold increase in geometric mean titres between pre- and post-vaccination sera or between pre- and booster vaccination sera.

¥GMT expressed as serum dilution giving the absorbance of 0.3 at $405 \mathrm{~nm}$; the sum of $\mathrm{IgG}$, IgM, and IgA antibody titres.

§Pre: sera taken just before vaccination; post: sera taken two to three weeks after primary vaccination; booster: sera taken two to three weeks after booster vaccination given two months after primary vaccination.

IgA antibody titres were found against types $6 \mathrm{~A}$, 14 , and 19. About half of these $\operatorname{IgA}$ responses were even higher than the corresponding IgG and/or IgM responses. When comparing the $\mathrm{JgA}$ antibody titres to the increase of total RIA antibody after primary vaccination, a positive correlation at the $\mathrm{P} \leq 0.01$ level was observed for types $14,18 \mathrm{C}, 19 \mathrm{~F}$, and $23 \mathrm{~F}$.

The frequency of detectable IgA titres increased with age so that all the six children over 5 years of

Table 3 Antibodies of the IgG and IgM classes against six pneumococcal polysaccharides as measured by ELISA in two age groups of children vaccinated with 14-valent pneumococcal capsular polysaccharide vaccine

\begin{tabular}{|c|c|c|c|c|c|c|c|c|c|}
\hline \multirow{4}{*}{$\begin{array}{l}\text { Pneumococcal } \\
\text { type }\end{array}$} & \multirow{4}{*}{$\begin{array}{l}\text { Blood } \\
\text { sample }\end{array}$} & \multicolumn{8}{|c|}{ Age at primary vaccination } \\
\hline & & \multicolumn{4}{|c|}{ 2-7 years (22 children) } & \multicolumn{4}{|c|}{ 6-18 months (7 children) } \\
\hline & & \multicolumn{2}{|l|}{$\operatorname{Ig} G$} & \multicolumn{2}{|l|}{$\operatorname{Ig} M$} & \multicolumn{2}{|l|}{$\operatorname{Ig} G$} & \multicolumn{2}{|l|}{$\operatorname{Ig} M$} \\
\hline & & $G M T^{*}$ & $\triangle G M T \dagger$ & $G M T$ & $\triangle G M T$ & $G M T$ & $\triangle G M T$ & $G M T$ & $\triangle G M T$ \\
\hline 3 & $\begin{array}{l}\text { Pre } \neq \\
\text { Post } \\
\text { Booster }\end{array}$ & $\begin{array}{l}235 \\
445\end{array}$ & $1 \cdot 9$ & $\begin{array}{l}270 \\
510\end{array}$ & $1 \cdot 9$ & $\begin{array}{l}155 \\
345 \\
390\end{array}$ & $\begin{array}{l}2 \cdot 2 \\
2 \cdot 5\end{array}$ & $\begin{array}{r}75 \\
130 \\
95\end{array}$ & $\begin{array}{l}1 \cdot 7 \\
1 \cdot 3\end{array}$ \\
\hline $6 \mathrm{~A}$ & $\begin{array}{l}\text { Pre } \\
\text { Post } \\
\text { Booster }\end{array}$ & $\begin{array}{l}310 \\
400\end{array}$ & $1 \cdot 3$ & $\begin{array}{l}535 \\
935\end{array}$ & $1 \cdot 7$ & $\begin{array}{l}150 \\
235 \\
305\end{array}$ & $\begin{array}{l}1 \cdot 6 \\
2 \cdot 0\end{array}$ & $\begin{array}{l}270 \\
515 \\
585\end{array}$ & $\begin{array}{l}1 \cdot 9 \\
2 \cdot 2\end{array}$ \\
\hline 14 & $\begin{array}{l}\text { Pre } \\
\text { Post } \\
\text { Booster }\end{array}$ & $\begin{array}{l}190 \\
210\end{array}$ & $1 \cdot 1$ & $\begin{array}{l}160 \\
250\end{array}$ & $1 \cdot 6$ & $\begin{array}{l}115 \\
205 \\
220\end{array}$ & $\begin{array}{l}1 \cdot 8 \\
1.9\end{array}$ & $\begin{array}{l}130 \\
155 \\
200\end{array}$ & $\begin{array}{l}1 \cdot 2 \\
1 \cdot 5\end{array}$ \\
\hline $18 \mathrm{C}$ & $\begin{array}{l}\text { Pre } \\
\text { Post } \\
\text { Booster }\end{array}$ & $\begin{array}{l}295 \\
865\end{array}$ & $2 \cdot 9$ & $\begin{array}{l}215 \\
335\end{array}$ & $1 \cdot 6$ & $\begin{array}{l}150 \\
475 \\
460\end{array}$ & $\begin{array}{l}3 \cdot 2 \\
3 \cdot 1\end{array}$ & $\begin{array}{r}65 \\
145 \\
135\end{array}$ & $\begin{array}{l}2 \cdot 2 \\
2 \cdot 1\end{array}$ \\
\hline $19 \mathrm{~F}$ & $\begin{array}{l}\text { Pre } \\
\text { Post } \\
\text { Booster }\end{array}$ & $\begin{array}{l}780 \\
950\end{array}$ & $1 \cdot 2$ & $\begin{array}{l}140 \\
360\end{array}$ & $2 \cdot 6$ & $\begin{array}{l}220 \\
395 \\
400\end{array}$ & $\begin{array}{l}1 \cdot 8 \\
1 \cdot 8\end{array}$ & $\begin{array}{l}120 \\
265 \\
165\end{array}$ & $\begin{array}{l}2.2 \\
1.4\end{array}$ \\
\hline $23 \mathrm{~F}$ & $\begin{array}{l}\text { Pre } \\
\text { Post } \\
\text { Booster }\end{array}$ & $\begin{array}{l}215 \\
335\end{array}$ & $1 \cdot 6$ & $\begin{array}{r}600 \\
1090\end{array}$ & $1 \cdot 8$ & $\begin{array}{l}135 \\
235 \\
215\end{array}$ & $\begin{array}{l}1 \cdot 7 \\
1 \cdot 6\end{array}$ & $\begin{array}{l}115 \\
320 \\
250\end{array}$ & $\begin{array}{l}2 \cdot 8 \\
2 \cdot 2\end{array}$ \\
\hline
\end{tabular}

*GMT (geometric mean titre) expressed as the dilution of the serum giving the absorbance of $0 \cdot 3$ at $405 \mathrm{~nm}$.

$+\triangle G M T$ : fold increase in geometric mean titres between pre- and post-vaccination sera or between pre- and booster-vaccination sera.

§Pre: sera taken just before vaccination; post: sera taken two to three weeks after primary vaccination; booster: sera taken two to three weeks after booster vaccination given two months after primary vaccination. 
Table 4 IgA antibody titres against six pneumococcal polysaccharides measured by ELISA in post-vaccination sera of 29 children vaccinated with 14-valent pneumococcal capsular polysaccharide vaccine*

\begin{tabular}{llll}
\hline $\begin{array}{l}\text { Pneumococcal } \\
\text { type }\end{array}$ & \multicolumn{2}{l}{ IgA titres $\dagger$} & \\
\cline { 2 - 4 } & No.positive $\neq$ & Range§ & $\begin{array}{c}\text { Geometric mean } \\
\text { titre } \S\end{array}$ \\
\hline 3 & & & 150 \\
$6 \mathrm{~A}$ & 17 & $65-490$ & 235 \\
14 & 16 & $50-815$ & 520 \\
$18 \mathrm{C}$ & 9 & $125-3310$ & 180 \\
$19 \mathrm{~F}$ & 16 & $75-605$ & 415 \\
$23 \mathrm{~F}$ & 14 & $125-890$ & 205 \\
\hline
\end{tabular}

* All pre-vaccination sera were negative (titre $<50$ ) for IgA class antibodies.

$\dagger$ Expressed as serum dilution giving the absorbance of 0.3 at $405 \mathrm{~nm}$.

$\$ 29$ sera tested in each case.

§Only positive sera included.

age produced IgA antibodies against all the six pneumococcal polysaccharides. After the booster vaccination IgA antibodies were found in only a few sera. These were the sera of children who had had a very high primary vaccination response compared with age.

\section{Discussion}

The ELISA method as described here is about as sensitive for measuring pneumococcal antibodies as the RIA that has been most commonly used so far. ${ }^{3}$ ELISA allows, however, for easy measurement of antibodies of different Ig classes and thus makes possible a detailed characterisation of the total antibody response. Recently, it has been shown by ELISA that pneumococcal antibodies in adult sera are of both IgG and IgM classes, and both of them increase after pneumococcal pneumonia ${ }^{11}$ or after vaccination with pneumococcal capsular polysaccharide vaccine. ${ }^{8}$ In these studies, IgA antibodies were not measured. The present ELISA results show that even very young children have detectable levels of IgG and IgM pneumococcal antibodies and either one or both increase as a response to primary vaccination with pneumococcal polysaccharides. The relative proportion of $\mathrm{IgG}$ and $\mathrm{IgM}$ antibodies was different for each individual pneumococcal polysaccharide. IgM antibodies were more often predominant in the sera of the older children (2-7 years) as compared with those of 6-18 months. Furthermore, the ELISA results show that the different Ig classes can decrease or increase between sera taken before and after primary or booster vaccinations while total antibody levels as measured by RIA may show only minor changes. Thus the total antibody levels for types $3,18 \mathrm{C}, 19 \mathrm{~F}$, and $23 \mathrm{~F}$ as a rule decreased between sera taken after primary and booster vaccination, while in fact there was an increase in IgG and a decrease in IgM and IgA class antibodies. IgA pneumococcal antibodies were not found before vaccination but were seen, even as the predominant class of antibodies, in post-vaccination sera. In fact the appearance and titre of the IgA antibodies showed a significant positive correlation with the increase of total antibody in response to the primary vaccination. The IgA response also had a positive correlation with the age of the child.

The total RIA antibody responses after vaccination agree with those described earlier. ${ }^{12-14}$ The ELISA results, expressed as the sum of separately measured IgG, IgM, and IgA antibody titres, correlated rather strongly with those obtained by RIA for five of the six types studied. A weaker correlation was found for type 6A. Callahan et al. ${ }^{10}$ have studied antibody responses to pneumococcal polysaccharide vaccine in adults by ELISA and RIA and found a poor correlation between these two methods. They suggest that their ELISA modification is not suitable for measuring vaccination responses to pneumococcal polysaccharides. More recently, however, Russel et al. ${ }^{9}$ showed in their preliminary study that their ELISA method was able to demonstrate immunological responses to each of the 14 type specific antigens of the pneumococcal polysaccharide vaccine. In general, the most common cause of discrepancies between ELISA and RIA results is believed to be that the ELISA technique is very sensitive to antibody affinity. ${ }^{17} 18$ Differences in the affinity of antibodies in individual sera should be seen as differences in the slope of the absorbance versus serum dilution curves. In the present study we did not see any marked variation of the slopes between the curves of different kinds of sera, neither were such differences observed by Leinikki and Pässilä who studied several viral antibodies. ${ }^{19}$ Secondly, competition between antibodies of different Ig classes can decrease the titre value of a certain Ig class in the ELISA test when low dilutions of sera are used. ${ }^{20}$ We tried to avoid this by registering the ELISA results at as high serum dilutions as possible. Thirdly, false-positive $\operatorname{IgM}$ values may be caused in ELISA by IgM antibodies of antiIgG specificity;21 this could hardly affect our results since the IgM responses we saw were different for every individual polysaccharide, and increases in IgM titre were seen in almost every individual within the two weeks' interval between consecutive serum samples.

On the basis of this study we feel that the ELISA technique is well suited to determining pneumococcal antibodies and antibody responses to pneumococcal vaccine. It is sensitive and easy to perform and does not require expensive equipment. It does not require 
radioactive antigens, which are not easily available. We have also successfully used the present ELISA method to determine antibody responses during pneumococcal disease, showing that it can be used for the serological diagnosis of pneumococcal infections (manuscript in preparation).

We thank Miss Raili Kalliokoski and Mrs Arja Vanhatalo for excellent assistance. This study was supported in part by a grant from Merck Sharp and Dohme Research Laboratories, West Point, Pa 19486, USA.

\section{References}

1 Amman AJ, Pelger RJ. Determination of antibody to pneumococcal polysaccharides with cromic cloride treated human red blood cells and indirect hemagglutination. Appl Microbiol 1972;24:679-83.

${ }^{2}$ Baker PJ, Stashak PW, Prescott B. Use of erythrocytes sensitized with purified pneumococcal polysaccharides for the assay of antibody and antibody-producing cells. Appl Microbiol 1969;17:422-6.

${ }^{3}$ Schiffman G, Austrian R. A radioimmunoassay for the measurement of pneumococcal capsular antigens and of antibodies thereto (abstract). Fed Proc 1971;38:658.

- Carenfelt C. Pneumococcal antibodies in maxillary sinus secretion. Scand J Infect Dis 1977;9:277-83.

${ }^{5}$ Sloyer JL Jr, Howie VM, Ploussard JH, Amman AJ, Austrian R, Johnston RB Jr. The immune response to acute otitis media in children. I. Serotypes isolated and serum and middle ear fluid antibody in pneumococcal otitis media. Infect Immun 1974;9:1028-32.

${ }^{8}$ Howie VM, Ploussard JH, Sloyer JL Jr, Johnston RB Jr. Immunoglobulins of the middle ear fluid in acute otitis media: relationship to serum immunoglobulin concentrations and bacterial cultures. Infect Immun 1973;7: 589-93.

7 Mouton RP, Stoop JW, Ballieux RE, Mul NAJ. Pneumococcal antibodies in IgA of serum and external secretions. Clin Exp Immunol 1970;7:201-10.

${ }^{8}$ Barret DJ, Amman AJ, Stenmark S, Wara DW. Immunoglobulin $G$ and $M$ antibodies to pneumococcal polysaccharides detected by enzyme-linked immunosorbent assay. Infect Immun 1980;27:411-7.

${ }^{9}$ Russel H, Edwards LR, Wortham EW, Facklam RR.
Enzyme-linked immunosorbent assay for detection of antibodies against Streptococcus pneumoniae capsular polysaccharides. J Clin Microbiol 1980;11:198-9.

${ }^{10}$ Callahan LT, Woodhour AF, Meeker JB, Hilleman MR. Enzyme-linked immunosorbent assay for measurement of antibodies against pneumococcal polysaccharide antigens: comparison with radioimmunoassay. $J$ Clin Microbiol 1979;10:459-63.

${ }^{11}$ Berntsson E, Broholm K-A, Kaijser B. Serological diagnosis of pneumococcal disease with enzyme-linked immunosorbent assay (ELISA). Scand $J$ Infect Dis o 1978;10:177-81.

12 Borgon̄o JM, McLean AA, Vella PP, et al. Vaccination and revaccination with polyvalent pneumococcal polysaccharide vaccines in adults and infants (40010) Proc Soc Exp Biol Med 1978;157:148-54.

${ }_{13}$ Hilleman MR, McLean AA, Vella PP, Weibel RE, Woodhour AF. Polyvalent pneumococcal polysaccharide vaccines. Bull WHO 1978;56:371-5.

"Weibel RE, Vella PP, McLean AA, Woodhour AF, Dawidson WL, Hilleman MR. Studies in human $\omega$ subjects of polyvalent pneumococcal vaccine (39894). Proc Soc Exp Biol Med 1977;156:144-50.

${ }^{15}$ Karma P, Luotonen J, Timonen M, et al. The efficacy of pneumococcal vaccination against recurrent otitis media. Ann Otol Rhinol Laryngol in press.

${ }^{16}$ Holmgren J, Svennerholm A-M. Enzyme-linked immuncsorbent assay for cholera serology. Infect Immun 1973: 7:759-63.

17 Butler JE, Feldbush TL, McGivern PL, Stewart N. The enzyme-linked immunosorbent assay (ELISA): a $\stackrel{\oplus}{.}$ measure of antibody concentration or affinity? Immunochem 1978;15:131-6.

${ }_{18}$ Minden P, Farr RS. The ammonium sulphate method to measure antigen-binding capacity. In: Weir DM ed. Handbook of Experimental Immunology. Oxford: Blackwell Scientific Publications, 1967:463-93.

19 Leinikki PO, Pässilä S. Quantitative. semiautomated, enzyme-linked immunosorbent assay for viral antibodies. J Infect Dis 1977;136:294-9.

${ }^{20}$ Keren DF. Enzyme-linked immunosorbent assay for immunoglobulin $\mathrm{G}$ and immunoglobulin $\mathrm{A}$ antibodies to Shigella flexneri antigens. Infect Immun 1979; 24:441-8.

${ }^{21}$ Leinikki P, Pässilä S. Solid phase antibody assay by means of enzyme conjugated to anti-immunoglobulin. $J$ Clin Pathol 1976;29:1116-20.

Requests for reprints to: Dr M Koskela, Department of Medical Microbiology, University of Oulu, Kajaanintie 46 D, SF-90220 Oulu 22, Finland. 